\title{
Five years in the news: A media analysis of Child, Youth and Family in two daily newspapers (2008-2012)
}

Barbara Staniforth and Liz Beddoe University of Auckland, New Zealand

\begin{abstract}
INTRODUCTION: This article describes a subset of data relating to the term "Child Youth and Family" from a media analysis of two major Aotearoa New Zealand newspapers from 2008 to 2012 and reports on the major themes emerging from a qualitative analysis of these articles.

METHODS: A search was conducted within the online versions of the New Zealand Herald and the Otago Daily Times for the years 2008 to 2012 on the search terms: "social work," "social worker" and "child youth and family." A qualitative thematic analysis of 1,512 articles within the data set "child youth and family" was conducted.
\end{abstract}

FINDINGS: Child Youth and Family (CYF) content overwhelmingly made up the largest data set and, within that subset, the reporting was principally related to crime and abuse. Social workers were seen mainly as receivers of referrals and of removing children and placing them in "care." There was little mention of intervention or treatment. There were many reports of the ways things went badly in the process, and at those times social workers were reportedly at the forefront.

CONCLUSION: The CYF content presents a limited view of social work, with potential implications for the scope of social work practice being limited to removal of children, and a reduction in the acknowledgement of the wider scope of treatment and intervention. There is also an emphasis on criticism of social workers when children are the victims of violence that occurs within a wider socio-political context.

KEYWORDS: social work; social workers; news media; media analysis, Child Youth and Family
In 2015, the Ministry of Social Development in Aotearoa New Zealand undertook a review of the state child protection agency, Child Youth and Family (Ministry of Social Development, 2015). One of the recommendations was a relaunch of the agency under the new name of the Ministry of Vulnerable Children Oranga Tamariki (MVCOT) which took place in April 2017. There has been considerable media coverage of this event, much of it critical in nature (see Hyslop, 2017; Staniforth, 2016).
Social work and child protective services are frequently subject to critical reportage (Franklin \& Parton, 1991). Studies of the public perceptions of social work have indicated that the public's knowledge of the profession is largely influenced by news media. One reason for this is that many people may never have met a social worker, nor are social workers particularly visible in popular culture (Zugazaga, Surette, Mendez, \& Otto, 2006). Reporting of social work stories in mainstream media is thus
AOTEAROA

NEW ZEALAND SOCIAL WORK 29(4), 5-18.

CORRESPONDENCE TO:

Barbara Staniforth b.staniforth@auckland. ac.nz 
understandably influential. This article aims to report on, and consider how, two major New Zealand newspapers portrayed the Child Youth and Family service (CYF) from 2008 to 2012.

This study was conducted as part of a multi-phase data collection project focused on public perceptions of social work. Other reported phases included a phone survey on this subject (Staniforth, Fouché, \& Beddoe, 2014) and an online survey on social workers' beliefs about public perceptions of social work (Beddoe, Staniforth, \& Fouché, 2017; Staniforth, Deane, \& Beddoe, 2016).

The contents of articles on two mainstream media outlets (New Zealand Herald, Otago Daily Times) mentioning social work/social workers /CYF were analysed over a fiveyear period (2008-2012). These newspapers were chosen for largely pragmatic reasons such as the availability of articles online for the selected period and limited resources for other methods of access. While the articles examined were from five years ago, the authors believe that there is value in the presentation of this data at a time of significant change in our child welfare services and that it is also important to form some kind of a baseline from which to view shifting media portrayal over time.

In this article, we present the findings of this search based on a qualitative analysis of the CYF data set and discuss the implications of these findings.

\section{Literature}

Several authors have explored the portrayal of social workers in print, film and television with mixed accounts. When social workers are portrayed in the media, the focus is limited and often revolves around child welfare. In an Irish study, Gaughin and Garrett (2012) found that reporting of social work and social services was focused mainly on work with children and families and further limited to reporting on child abuse cases.
Davidson and King (2005) undertook a largescale study on the perception of social work in Scotland. In commenting on their focus groups, they noted that:

In all groups there was spontaneous reference to the "bad press" that social workers receive, with participants generally feeling that this is perhaps unfair and a reflection of a broader tendency on the part of the media to highlight bad rather than good news (p. 25).

Social workers' negative views of media have been reported by Davenport and Davenport (1997) who noted that a "prevailing view" held by students, educators and practitioners, was "that [social workers] are typically featured in unflattering, negative terms such as child snatchers, ineffective do-gooders, fuzzythinking liberals, parasites on the public purse, and self-serving bureaucrats" (p. 11). Zugazaga et al. (2006) conducted a study of 665 MSW social workers in Florida, USA and found that participants believed that the profession was "depicted negatively in both news and entertainment media" (p. 621).

More recently, in Aotearoa New Zealand, an online study of social workers' views on the public perception of social work asked for social worker response to the statement "How do you think that the media portrays social workers in this country?" A total of 305 out of 344 (88.6\%) participants answered either "doesn't portray them very well" or "portrays them really badly" (Staniforth et al., 2016).

Several studies have explored the presentation of social work in child welfare, particularly following tragic cases of child death. Garrett (2009) comments upon the media coverage following the death of "Baby P "in Britain in 2007. He details the portrayal of "'monstrous' and incompetent public sector social workers" (p. 536) and describes how the social workers and their supervisor were seen as "being responsible for the death of a baby" (p. 537). 
Briar-Lawson, Martinson, Briar-Bonpane, and Zox (2011, p. 186) note a problematic outcome of such negative reporting: "Even when culpability for the handling of a troublesome high-profile child welfare case is eventually assigned to another system outside of child welfare, the media scrutiny, rapid finger pointing, and accusations make the job of protecting children extraordinarily difficult." A recent Swedish study by Blomberg (2017) of 586 online media stories about social work described including a "child abused" narrative where social workers were criticised and blamed for not being able to stop serious abuse and violence.

Little scholarship of media portrayal of social work has been undertaken in Aotearoa New Zealand since the 1990s (see for example, Blank, 1999; Lytollis, 1996) other than recent work undertaken by the present authors. Several studies have noted the disproportionate reporting of child abuse deaths of Māori children (for example, Beddoe \& Cree, 2017; Merchant, 2012; Provan, 2012). Provan (2012, p. 202) noted that murdered Māori children are more likely to be named in a "'roll of dishonour,' thus framing family violence as solely a Māori problem." The focus of this article however, is on the media framing of social workers associated with CYF.

\section{Method}

The research began in 2013 by exploring five years (2008-2012) of online reports from two newspapers, the New Zealand Herald (NZH) and Otago Daily Times (ODT), searching for the terms "social work," "social worker" or "Child Youth and Family." Identical articles might appear in all three categories and in both newspapers. Table 1 lists the breakdown of the number of articles/sources and key terms for the data collection results for each of the five years.

Items ranged from a few words in an article, otherwise unrelated to social work, to occasional longer features and opinion pieces written by an academic. Most items were short news reports (such as in the court or crime report sections). There were multiparagraph stories with headlines featuring the terms "social worker" or "CYF," sometimes with a series of follow-up stories and discussion over a number of days, repeated in both newspapers.

The qualitative analysis of the data set used a general inductive approach (Thomas, 2006) for initial review and coding, with a research team member reading over the material and developing codes into an initial coding framework for team discussion and review. The framework was developed to cover any aspect of social work as a profession that might be reported on. The coding framework and media data set was set up in $\mathrm{NVivo}^{\mathrm{TM}}$ and items were coded and reviewed.

A constructionist thematic analysis approach was then used (Braun \& Clarke, 2006) where initial codes generated systematically across the data set were developed and refined into broad ideas or "themes," showing how media reports "construct" social realities such as social work. Our analysis and interpretation of themes was informed by a body of constructionist analysis of media in diverse fields including, for example, on mental illness in New Zealand (Nairn, 2007) and child obesity in Australian print media (Zivkovic, Warin, Davies, \& Moore, 2010). Illustrative quotes and examples were drawn from the data set to encapsulate the themes, and interpretation of examples also drew from positioning theory (Allen \& Wiles, 2013) in highlighting use of discursive strategies and language (Potter \& Wetherell, 1987) to "position" social workers and CYF in certain ways. Overall, our analyses and interpretations were informed by our own "positioning" as social workers endorsing critical and anti-oppressive social work theories.

In the findings sections that follow, the analysis has been limited to the CYFrelated material. Wherever possible, names and other identifying material have been removed or initials only have been used for ethical reasons ${ }^{\mathrm{i}}$. 
Table 1: Data Set

\begin{tabular}{|l|c|c|c|c|c|c|}
\hline $\begin{array}{l}\text { New Zealand Herald } \\
\text { Key Terms }\end{array}$ & 2012 & 2011 & 2010 & 2009 & 2008 & Total \\
\hline social work & 19 & 13 & 19 & 23 & 13 & 87 \\
\hline social worker & 53 & 51 & 65 & 57 & 56 & 282 \\
\hline $\begin{array}{l}\text { Child, Youth and } \\
\text { Family }\end{array}$ & 178 & 197 & 206 & 157 & 201 & 939 \\
\hline Total & 2012 & 2011 & 2010 & 2009 & 2008 & 1,308 \\
\hline $\begin{array}{l}\text { Otago Daily Times } \\
\text { Key Terms }\end{array}$ & 24 & 18 & 26 & 17 & 14 & 99 \\
\hline social work & 58 & 51 & 52 & 72 & 45 & 278 \\
\hline social worker & 107 & 98 & 138 & 121 & 109 & 573 \\
\hline $\begin{array}{l}\text { Child, Youth and } \\
\text { Family }\end{array}$ & & & & & & \\
\hline Total & & & & & & 950 \\
\hline Total both papers & & & & & & 2,258 \\
\hline
\end{tabular}

\section{Findings}

\section{Limited scopes}

The breakdown in Table 1 demonstrates the first important finding: when CYF-related items were removed from the data set, there were very few activities and attributes reported in media portrayals of social work and social workers.

Within the CYF data set, social work was an activity overwhelmingly concerned with issues of abuse/violence and crime. Social work interventions were primarily related to assessment and risk management, and the closely associated interventions of providing/arranging custody and care. Those requiring social work intervention were primarily babies and children (with some necessary engagement with adults in their roles as parents/caregivers), and some teenagers/youth (primarily under age 16). The justice system and police were the government agencies with which social work had the most dealings. This portrayal was consistent across the five years of the data, and across both newspapers.

Looking in more detail at the portrayal of the limited range of issues and interventions in which social work and social workers engaged, the data were analysed to identify themes from both the content and form of the activities and attributes reported.

Key themes included CYF primarily having discreet "receiver" and "remover" roles positioned as being on the side of the community in removing children from known, named abusers or criminals. When these roles were ineffective, however, social workers became more visible (and vilified); authority figures were portrayed by media as criticising social workers, and various types of failures, in custody and care, and in treatment and support, were presented. The theme of failure also contributed to a theme of social work as a target needing to be changed by social policy. 


\section{Referrals and removals}

Social work, as enacted by CYF, was primarily portrayed as being about the beginning and end of the story. CYF was reported as having been informed or called in at the start of something, or were given the task of removing, placing or taking care of children at the end of an incident being reported. Thus, the interventions (what they did) most engaged in by social workers, according to media portrayals, were initial assessments of child safety and management of child abuse risk, and custody and care (as opposed to treatment and support, preventative work or other types of interventions).

CYF was also reported as having been "informed," "notified," or asked to "investigate" as some story of abuse, violence or crime unfolded. CYF was thus noted as a passive recipient of information, or of a call or request to investigate, in their key task of assessment and risk management; this can be characterised as the agency playing a role as "receiver." Table 2 presents examples from the data set regarding the receiver role.

Alternatively, CYF was mentioned at the end of a story as having "removed" children or as having "taken [them] into CYF care" at the conclusion of incidents or incident reports. The intervention of custody and care can be characterised as the agency playing a role as "remover" - CYF was portrayed as the agency that takes away and, as necessary, finds a different place to put a child, such as placing in "care" or with a relative. Table 3 demonstrates examples of CYF social workers in their removing role.

The remover role was portrayed as discreet and necessary; removed from somewhere or someone who was bad and "placed" somewhere better; "taken into care" where care was both some sort of unspecified physical location (foster-care homes, care and protection residences) and also some sort of activity of "care" that was provided by unspecified people who were not "the mother" or "the man," or whoever had been causing harm.

Sometimes care was shared ("CYF and the girl's grandparents") but mostly, CYF took young victims into "care" and took young offenders into "custody" or "secure care."

Particularly problematic children could also be "returned" to CYF.

The remover role was primarily conducted by the faceless agency, "CYF,", but occasionally, there was a reference to people involved, namely "caregivers" as "appointed" or "approved"; this was generally in more detailed accounts, including eyewitness statements, as in the following:

A neighbour of the twins told the Herald on Sunday the defendant's family, including six children, had moved out of their home of eight years on Wednesday. "She has gone to her mum's ... and the kids were taken away by

Table 2: The Receiver Role

\begin{tabular}{|l|l} 
Receiver role & Illustrative examples \\
\hline $\begin{array}{l}\text { Passive recipients of } \\
\text { requests for involvement }\end{array}$ & $\begin{array}{l}\text { CYF to investigate baby death.i CYF has been asked to investigate urgently } \\
\text { the circumstances surrounding the death of a child who was suffocated by his } \\
\text { intoxicated mother. [NZH, May 30, 2012] }\end{array}$ \\
$\begin{array}{l}\text { Drunk mother took son (10) to Dunedin pub. A Dunedin family has been } \\
\text { referred to CYF after a woman took her 10-year-old son with her to the pub at } \\
\text { 2am on Sunday. [ODT, 5/04/2011] }\end{array}$ \\
[Newborn abandoned on aircraft] CYF was notified and Immigration officials \\
were checking if correct procedures were followed. [ODT, 19/03/2009]
\end{tabular}


Table 3: The Remover Role

\begin{tabular}{|l|l|}
\hline Remover role & \begin{tabular}{l} 
Illustrative examples \\
\hline Take away, remove, and "place" children
\end{tabular} \\
$\begin{array}{l}\text { Both the boy and his three-month-old baby sibling have been } \\
\text { removed from the mother's custody and placed into CYF care. } \\
\text { [NZH, ODT, 05/10/2012] } \\
\text { Homicide probe into woman's death. CYF were also called to } \\
\text { the scene and removed six children and two teenagers. [NZH, } \\
11 / 07 / 2010]\end{array}$ \\
\hline $\begin{array}{l}\text { Young offenders are removed into } \\
\text { "custody" or "secure care" }\end{array}$ & $\begin{array}{l}\text { Firefighters were called to another toilet fire at another public } \\
\text { area about 8.30pm, and police found the boy nearby. The arresting } \\
\text { officers handed him over to CYF. He would appear in the Family } \\
\text { Court in New Plymouth today. [ODT, 23/11/2009] }\end{array}$ \\
\hline
\end{tabular}

CYF," she said. ... CYF northern [regional director] confirmed all of the children were living with appointed caregivers. [ODT, NZH, 22/07/2012]

In this remover role, CYF was also portrayed as being on the side of the general population in protecting infants from known offenders whom the media had named. For example, under the headline, NG abuser pregnant, OK [convicted for assault], was reported as being pregnant and:

It is likely [convicted woman's] new baby will be taken into CYF care at birth, sources have indicated.

[NZH, 14/10/2012]

In reports on $\mathrm{CS}$ whose boyfriend, $\mathrm{ME}$, killed her infant daughter, CYF was portrayed as part of a positive "community" response to violence, where ME's arrest was described by police as "testament to the ... community, who would not tolerate violence to children and had rallied behind police" with the "very strong relationship" with CYF who had provided "invaluable" assistance in the case. CYF was again portrayed as an unnamed rescuer removing CS's children:

On January 6, CS gave birth to a child fathered by ME. CYF took the baby less than 48 hours later. CS's 6-year-old son has been in CYF care since the incident last year.

[NZH, 30/01/2012]
There was a rare elaboration voiced by a named CYF representative in this case, including acknowledging the complex issues around removing children as being a decision "never taken lightly":

The source said CS was "absolutely" trying to have her two children, one of whom was fathered by $M E$, returned to her care ... [the] regional director, said ... "The decision to remove a child from their parent's care is never taken lightly," said [the director]. "We removed both of these children because we held serious concerns for their safety." [NZH, 11/02/2012]

Very occasionally, the challenging nature of the remover role, in terms of assaults on caregivers and need for further removal, was explained:

An "out of control" 11-year-old recidivist burglar is likely to be in custody for months after assaulting caregivers he was placed with just one day ago in Napier.

The Napier boy was put into a secure CYF group home yesterday after he allegedly helped rob four houses .... [NZH, 12/04/2012]

[Sergeant], who is in charge of youth services in Napier, said the boy was being transferred to an Auckland secure care facility reserved for "hard to handle" youth offenders today. [NZH, 12/04/2012] 
These portrayals located the problems within the children - out of control, frustrated, hard to handle - thus, failures of social workers to remove or "place" were not levelled at CYF but at the individual children's behaviour.

Thus, the primary portrayal of social workers was that they were unidentified operatives who passively received and processed information or tasks, narrowly focused on abuse, violence and crime, in a receiver role. There was also a portrayal of a more active remover role, discreetly shifting, placing and removing victims and offenders as required. This could be more visible and somewhat heroic when portrayed as backing up the needs of the wider community to be watchful of, or protected from, known or notorious figures. While CYF was, in fact, the mandated agency tasked with receiving information (and at times removing children at risk of harm), this portrayal is in contrast to the wider roles espoused by MVCOT which states: "We support children, family and whānau to restore their mana, their sense of self, their important connections and relationships, their right to heal and recover, and reach their potential" (MVCOT, 2017).

\section{When things go wrong, social workers are more visible}

The placement of the information within news reports shifted when there were failures. Where the receiving or removing functions were not effectively carried out, the information was presented at the outset, often in a strong headline. For example, the dramatic juxtaposition of "baby girl" and "sex offender" headlines a story of a failed placement:

CYF left baby girl with sex offender for 15 months. CYF has admitted it could have done better after leaving a baby girl with a convicted sex offender for more than 15 months because it was told he was her father. [NZH, 9/06/2012]
The use of the active statement, "CYF left" the girl, increases the sense of blame, as if there was an intention to have left the child in harm's way.

In addition, in media portrayals of things going wrong, the anonymous, faceless, singular institution "CYF" was more likely to be populated by "social workers":

\section{Social workers took four years to take children from a woman accused of beating and neglecting them, despite the pleas and warnings of family and police. [NZH, 14/10/2012]}

She [the teacher] dealt with at least six CYF workers. "I wanted to scream at these people it was so frustrating." [NZH, 14/06/2009]

There were also more likely to be named senior CYF managers who were engaged in "admitting" failures or promising to do better. For example, the named head of CYF outlined how social workers had failed in specific tasks in this case:

The case caused a storm of controversy when the mother was sentenced, with the head of CYF admitting social workers failed the girl and that the case highlighted the need to improve practices. BM said there was no doubt her organisation should have done a better job, citing failures by social workers to visit and monitor the girl, to respond to concerns raised by her school and to work effectively with other agencies involved. [ODT, 07/02/2012]

The sense of families being supported or working with CYF also disappeared when there were failures, again emphasised in a headline in relation to a 13-year-old's attempted suicide:

Boy's family frustrated with CYF. The family of a 13-year-old who ended up in the intensive care unit for three days after overdosing on epilepsy pills says the child will not be safe until CYF place him in a secure residence. ... He had been sent to stay at CYF 
family homes, but repeatedly absconded, often committing crimes while he was out.... The boy's father said he was frustrated with CYF's "pathetic" approach to the child, despite the agency having worked with the boy for several years and being fully aware of his behaviour when it took custody of him. CYF regional director southern KA said the child was now under extra supervision and a team of specialists would meet this week to look at a range of longer-term placement options for him. [ODT, 05/062012]

Only at the very end of this relatively long report, with its extensive quotes of complaint about CYF, was there an elaboration from the CYF spokesperson about aspects of the family's conduct over the years of intervention:

She said CYF started working with the boy in 2009, following concerns of violence in the family home. He had a history of challenging behaviour, which continued despite several interventions. There had been times when both the "young man" and his family had not stuck to care plans, which made it more difficult to help turn his behaviour around, she said. [ODT, 05/06/2012]

\section{Lack of support from "above"}

Authority figures, such as judges and coroners, were portrayed as critical of CYF. One headline put a judge in the role of remover/rescuer: "Horrified judge rescues children":

A judge has slammed the reckless actions of CYF workers who allowed four children to stay with their violent, abusive parents for more than nine years. Social workers failed to respond to 20 warnings that the children were being abused and neglected by their father, a convicted child rapist, and their mother, who left them alone in a South Auckland car park. The case has alarmed Family Court judge Dale Clarkson so much that she has referred it to the Children's Commissioner. [NZH, 15/12/2012]
The parents have had their children removed from them, but the "more severe comments" by the judge are reported as being "reserved" for CYF, when the issues are assumed to be "indicative of CYF's practice." Another authority figure, "head of New Zealand's largest anti-domestic violence agency" was quoted in this item as also generalising the situation to a "systems failure" across the agency.

Another authority figure, a coroner, was reported as "taking aim" and "pointing the finger" at CYF's failures although, in this headline, the parents are also mentioned as responsible:

Coroner takes aim at parents, CYF over baby's death. A coroner has pointed the finger at unacceptable parenting in the last days of a toddler's life and a failure by CYF to assess her safety as contributing factors in her death. [NZH, 29/02/2012]

Politicians regularly featured in media reports of bad placements or complaints, either joining the general expressions of dismay being reported or, promising remedies through changed legislation or compensation. CYF spokespeople were also called on to make statements about actions taken. The following newspaper report gave an account of responses to a TV news programme's portrayal of a bad CYF placement, where the politician promises a new compensation process, and CYF apologises and reports that changes were made:

\section{Social Development Minister Paula Bennett is encouraging people who were abused as a result of the state being involved in their care, including placement with wider family or in foster homes, to apply for compensation. [NZH, 27/06/2012] \\ There are many ways that things can go wrong...}

As noted, the remover role of CYF providing custody and care was mentioned at the end 
of many crime and abuse reports. When this role was not effectively conducted, there was an emphasis on naming the agency or referring to "social workers" in headlines and opening paragraphs.

\section{CYF says sorry for placement slip-up.}

[NZH, 27/12/2011]

\section{Toddler death: $C Y F$ role reviezwed.} [ODT, 06/06/2008]

Abused ... then abused again. Almost 1800 children whose abuse or neglect was detected by social workers last year were re-abused within six months, often by the same parents or family members. [NZH, 14/11/2009]

There was also a range of ways portrayed in which the role of remover into custody and care could go wrong. Most focused on individual cases where there had been placements to the wrong people (including CYF caregivers or family members). Ability to "escape" or "abscond" from placements, resulting in harm to the escapee or members of the public also featured. There was coverage over there not being enough placement options and facilities. The issue of too many placements over the child's lifetime was also a recurring theme. Table 4 demonstrates examples of "when things go wrong."

Sometimes numbers were indicated to put some of these situations in perspective but this was the exception rather than the rule. For example, under the headline, Dozens of children abused while in CYF care, was the following:
More than 70 children and young people were abused while in CYF care last year and no central records are being kept on the abuse. Social Development Minister Paula Bennett revealed the information in Parliament today in response to a question from the Greens' Holly Walker. Ms Bennett said that of the 71

Table 4: Custody And Care Gone Wrong

\begin{tabular}{|c|c|}
\hline Custody and care & Illustrative examples \\
\hline $\begin{array}{l}\text { Taken away and "placed" with the } \\
\text { wrong people, including family or CYF } \\
\text { caregivers: }\end{array}$ & $\begin{array}{l}\text { TK's childhood had been disrupted and abusive so CYF intervened } \\
\text { and placed her with her mother's half-sister who turned out to be a } \\
\text { methamphetamine user. [NZH, 15/11/2012] } \\
\text { Sex case conviction brings CYF apology. CYF has apologised for } \\
\text { "tragic and unacceptable" failings that led to the indecent assault } \\
\text { of a 13-year-old girl by one of its own carers. [NZH, 19/11/2010] }\end{array}$ \\
\hline $\begin{array}{l}\text { Not enough placement options or } \\
\text { facilities }\end{array}$ & $\begin{array}{l}\text { Youngsters held in police cells. ... In Dunedin, a 16-year-old spent a } \\
\text { night last week in a Dunedin Central police station cell because no } \\
\text { beds were available in secure youth facilities. [ODT, 18/08/2010] } \\
\text { No CYF beds available at times. Young people placed in the custody } \\
\text { of CYF are sometimes having to stay back in their family homes } \\
\text { immediately after being transferred to CYF because appropriate } \\
\text { caregivers and beds are not available. CYF denies there is an issue } \\
\text { with the availability of caregivers, and says it is "very rare" that } \\
\text { a child or young person cannot be placed at least somewhere } \\
\text { temporarily until a specialist caregiver or placement comes } \\
\text { available. [ODT, 27/02/2012] }\end{array}$ \\
\hline Too many placements and moves & $\begin{array}{l}\text { But at } 13 \text { his behaviour began to deteriorate after he was sexually } \\
\text { abused by "someone who lived near the family home". His mother } \\
\text { could not handle his behaviour and he was shuffled, he told a } \\
\text { court-appointed psychologist, between } 57 \text { CYF foster homes over a } \\
\text { three-year period. [NZH, 14/06/2012] }\end{array}$ \\
\hline
\end{tabular}


cases of abuse - 30 were by CYF-approved caregivers and the rest by "third party" caregivers. [NZH, 17/07/2012]

This is an example of an article where the numbers would have been useful to put it in perspective - the Minister states: "The figure equated to less than 1 per cent of all caregivers. International figures ranged from 0.5 per cent to 7 per cent". The main point of this article could therefore equally have been expressed as something like: "More than 120,000 care and protection notifications included just 13 police prosecutions against CYF-approved or third-party caregivers, lower than international rates."

Similarly, there was occasionally a more nuanced account around the supposed lack of placement facilities, backed up by police, not just CYF:

An "unfortunate set of circumstances" resulted in a 15-year-old boy being held in a police cell at the Dunedin Central police station for four nights over Easter, police say. [ODT, 13/04/2012]

Moreover, while there was an occasional report about not keeping data on lack of placement facilities, this was a rare concern, compared to the dozens of routine items portraying CYF as "removing" and "placing" as needed:

No CYF centralised placement data. CYF is unable to say how often it has not been able to find immediate accommodation for a child or young person placed in its custody, as it does not keep centralised data. [ODT, 31/03/2012]

The scale of this work was occasionally referred to, again potentially putting into perspective the tasks CYF faced:

There were 124,291 "care and protection notifications" to CYF during the 2009/10 year. [NZH, 25/07/2012]

In 2011, CYF removed 148 babies either at birth or within a month. In 2010, it removed 177. [NZH, 07/06/2012; ODT, 08/06/2012]

\section{Treatment and support}

Based on this data set, there was little media coverage of effective interventions of treatment and support by CYF social workers. In reviewing the items from the media data set categorised as "interventions", these were overwhelmingly "assessment and risk management" and "custody and care", as noted. To some degree, these were one and the same intervention - the child would be placed in the custody and care of CYF in order for assessment and risk management processes to be enacted, or following assessment and risk management, custody and care would be arranged.

Interventions beyond these largely crime/ abuse-related tasks were rarely portrayed in the data set. Interventions categorised as treatment and support included any mention of treatment interventions, programmes, and support plans; often delivered by NGOs under contract to CYF. Typically, in reports on an issue or service (such as social media safety, or a youth health centre opening), there were contact details or just the agency name listed as potentially of help with treatment and support. Placement of this information was usually at the end of the media report:

Any schools with concerns about this issue [a dangerous game spreading at schools] or needing further support can ring the Ministry's Traumatic Incident helpline on.... [NZH, ODT, 12/11/2012]

In contrast to the plethora of short news reports, there were occasional longer feature articles, where a journalist endeavoured to bring to life the work of CYF. The journalist at times assessed the quality of the work going on, which sometimes included positive appraisals of treatment and support.

Under the heading, Ray of hope in youth crime gloom, a senior feature-writer described sitting in on a family group conference for a youth offender. The tagline explains, "It's good to see a court family 
conference end with a 15-year-old looking like he's getting sorted" [NZH, 14/11/2012]. Similarly, a writer for the lifestyle magazine section of a paper, was "given rare access" to spend time with CYF social workers, and mused on the "pleasant" office environment (and the "smell of freshly-baked scones"):

New Zealand has a shocking child-abuse record but the social workers dealing with the heartache behind the headlines are a mystery to most people. Kim Dungey was given rare access to spend a day at CYF.

... the pleasant environment belies the disturbing reality these care-and-protection social workers face daily. The 38-strong team is constantly balancing existing caseloads with urgent incoming work and support for families with children's safety - each decision potentially life-changing. ... But ask why New Zealand's rate of child-abuse cases is so high and there is a long silence. [ODT, 01/042012]

Other treatment and support examples included a mother who had had children previously removed by CYF, and was effectively supported by the agency to care for her newborn:
CYF staff regularly visited and found his mother appeared to be complying with the discharge plan and was abstaining from alcohol. [NZH, 20/11/2012]

\section{Failed treatment and support interventions are common}

In contrast, reported unsuccessful CYF treatment and support ranged from a failure to organise the necessary interventions, through interventions being ineffective or incomplete, through to being avoided by those needing them. Table 5 shows a snapshot of examples from 2012.

Again, in a longer-form opinion piece, "Your Say", a social work lecturer, Emily Keddell, tried to explain the complex issues of providing effective treatment and support:

However, a focus on increasing resourcing for surveillance and detection does not increase resourcing for the intensive, relationshipbased family work that must be done with many families for whom their children will not be removed, or will be removed in the short term then returned, or with the new carers for children who are served up the double whammy of abuse from their parents then removal to foster care.

Table 5: Unsuccessful Treatment and Support

\begin{tabular}{|l|l|}
\hline Treatment and support & Illustrative quotes \\
\hline Failed to organise & $\begin{array}{l}\text { Teenage murderer failed by CYF - Step-father. ... CYF failed to organise } \\
\text { the counselling the boy needed. [ODT, 21/12/2012] }\end{array}$ \\
\hline Ineffective programmes & $\begin{array}{l}\text { The student had been referred to the Rock On programme - an inter- } \\
\text { agency truancy programme which includes Truancy Services, CYF, a Youth } \\
\text { Aid police officer, a guidance counsellor and other agencies when needed } \\
\text { - but continued to be absent from school. [NZH, ODT, 11/09/2012] }\end{array}$ \\
\hline $\begin{array}{l}\text { Parents work with CYF but it } \\
\text { doesn't help }\end{array}$ & $\begin{array}{l}\text { [Parents] had done everything they possibly could to get their daughter to } \\
\text { school and worked with the police and CYF. "She just won't go to school } \\
\text {.. She will stay half an hour and run away. It's an extremely unfortunate } \\
\text { situation". [NZH, ODT, 18/O6/2012] }\end{array}$ \\
\hline Help provided but not enough & $\begin{array}{l}\text { Parents fear their teen son will kill. ... The [parents] have done parenting } \\
\text { and behavioural courses and have taken part in a family meeting run by the } \\
\text { Youth Justice branch of CYF. [but these have been ineffective at managing } \\
\text { their 14-year-old's out-of-control behaviour]. [NZH, ODT, 31/08/2012] }\end{array}$ \\
\hline $\begin{array}{l}\text { Teens can avoid ongoing } \\
\text { involvement }\end{array}$ & $\begin{array}{l}\text { [A 16-year-old had applied for independence from CYF; later commits } \\
\text { suicide] Attempts by CYF and [the] District Health Board to hold meetings } \\
\text { with [family] were unsuccessful, Mr Smith said. [NZH, 1/11/2010] }\end{array}$ \\
\hline
\end{tabular}


It's clear that the outcomes for children, whether they are removed or not, are better if the social worker is able to build a highquality relationship with their parents. A primary emphasis on detection and risk assessment alone threatens the social worker's ability to do this. [ODT, 06/08/2012]

\section{Social work as a target needing to be changed by social policy}

The domain of social policy in relation to the activities and roles of CYF was reported in the media from time to time.

A case where a stepfather was charged with 7-year-old boy's death showed the local MP getting involved:

MP calls for inquiry into boy's death. Nelson MP Nick Smith is calling for an independent inquiry into whether CYF and other welfare agencies provided enough support to the family of a Nelson boy who died after an alleged assault. [NZH, ODT, 05/07/2008]

The CYF spokesperson was reported as denying involvement:

CYF had twice been notified about the family, but deputy chief executive Ray Smith said neither of the notifications had indicated the boy's safety was at risk. Other agencies had also been involved in supporting the family, and CYF had not been involved with the family at the time of the boy's death, Mr Smith said. [NZH, ODT, 05/07/2008]

\section{Some concluding thoughts}

It is concerning that social work at CYF has been presented in such a limited scope. The view that social workers are passive recipients of information that results in assessment, with limited options other than leaving children in place without supports, or removing them, is concerning and corresponds with neoliberal frameworks in child welfare that emphasise risk assessment technologies with little room for social workers to engage in relation-based therapeutic interventions (Hyslop, 2013, 2016).

In the media portrayals reported here, social workers largely moved into view, populated the stories and were visible in proportion to the extent of their failures. This was rarely to the extent of an individual front-line worker being named (except where criminal charges were laid), but went at least to their named supervisors and managers. The named leaders commented on orderly business from time to time, especially where the agency was positioned on the side of the community against high-profile, or particularly notorious perpetrators.

In positive preventative roles, their presence disappeared again into the list of other agencies involved, or the list of names and numbers as a back-up to the good work of non-governmental leaders or groups, or police/justice/health professionals leading a promising government initiative. Occasionally, a glimpse of a noble, quietly heroic social worker was shown - sitting overnight with a teenager who could not be placed in an appropriate custodial setting, saying a prayer for a promising teen, or showing a journalist, with privileged behindthe-scenes access, that specific children can be helped.

It could be argued that the invisibility of social workers was inevitable, given the age of the service user population, and the nature of the issues and allegations being portrayed. Or could the scale of work be more often noted - for instance the 100,000s of "routine" notifications and investigations being conducted?

Alongside the people, the places - homes, secure facilities, short-term, long-term occasionally moved into the frame of the media portrayals, as did laws or data processing, but the vivid narratives of harm to vulnerable children, especially where associated with CYF failure, provided many more column inches. This limited portrayal is 
consistent with research described previously and is significant for many reasons. With an aging social worker population in New Zealand (Geoff Pearman Partners in Change, 2011), high staff turnover in child protection and increasing rates of reported abuse (Modernising Child Youth and Family Expert Panel, 2015), new and younger social workers need to be attracted to the field of child protection and wellbeing, and those who are there need to be acknowledged for the varied and valuable contributions that they make.

There are limitations to this research. The collection of data over the study period provides a snapshot of media coverage in a specific timeframe and cannot be seen as generalisable to other places or times. As Chenot (2011) noted, there is a cycle of reportage on child protection issues. Since the time of data collection, the newly formed MVCOT has replaced CYF and promises a shift towards a view of "trauma informed practice" which is sometimes portrayed as outside the scope of social work practice (Hyslop, 2017).

At the time of writing, the Social Workers Registration Board is preparing for mandatory registration of social work with consideration of social work definitions and scopes of practice. There is a danger here that the limited views of social work practice within a child protection field may be influenced by the narrow depiction of social work roles in MVCOT. In addition, citizens increasingly contribute to policy discourses, especially about social problems, using online comments, blogs, Facebook and other media to add a range of opinions to the mix (Stanfield \& Beddoe, 2016). An excellent opportunity for further study is presented by the media and public reactions to this current shift to a new agency and ways of working.

Social work educators, the professional social work association and practitioners need to be vigilant that the many roles that they engage in are not narrowly prescribed by limited scopes of practice defined by employers or by the State (Re-Imagining Social Work Collective, 2017). The time to ensure that this does not happen, is now.

\section{Notes}

Many of the articles in the data set relate to traumatic events and tragedies. The authors have chosen not to add to the myriad media exposures of children and their families as in this instance they are not the focus of our study.

i Bolded italics with a full stop are used to denote a headline.

\section{References}

Allen, R. E. S., \& Wiles, J. L. (2013). The utility of positioning theory to the study of ageing: Examples from research with childless older people. Journal of Aging Studies, 27(2), 175-187.

Beddoe, L., \& Cree, V. E. (2017). The risk paradigm and the media in child protection In M. Connolly (Ed.), Beyond the risk paradigm in child protection (pp. 15-28). London, UK: Macmillan Education.

Beddoe, L., Staniforth, B.L., \& Fouché, C. (2017). "Proud of what I do but often I would be happier to say I drive trucks": Ambiguity in social workers' self-perception. Qualitative Social Work, 0(00), 1-17.

Blank, A. (1999). Māori the media, racism and neglect. Social Work Now, 14, 41-45.

Blomberg, H. (2017). "We're not magicians! On the use of rhetorical resources in Swedish news media narratives portraying the social services and social workers. Qualitative Social Work, 0 (00), 1-18. doi:10.1177/1473325017710324

Braun, V., \& Clarke, V. (2006). Using thematic analysis in psychology. Qualitative Research in Psychology, 3(2), 77-101. i:10.1191/1478088706qp063oa

Briar-Lawson, K., Martinson, K., Briar-Bonpane, J., \& Zox, K. (2011). Child welfare, the media, and capacity building. Journal of Public Child Welfare, 5, 185-199.

Chenot, D. (2011). The vicious cycle: Recurrent interactions among the media, politicians, the public, and child welfare services organizations. Journal of Public Child Welfare, 5(2-3), 167-184. doi:10.1080/15548732.2011.566752

Davenport, J. A., \& Davenport, J. (1997). Social workers: Fad chasing jackasses or still on the side of the angels. The New Social Worker, 4(1). Retrieved from http://www.socialworker.com/media.htm

Davidson, S., \& King, S. (2005). Public knowledge of and attitudes to social work in Scotland. Edinburgh, UK: Scottish Executive Social Research.

Franklin, B., \& Parton, N. (Eds.). (1991). Social work, the media and public relations. London, England: Routledge.

Garrett, P. M. (2009). The case of "Baby P": Opening up spaces for debate on the "transformation" of Children's Services? Critical Social Policy, 29(3), 533-547.

Geoff Pearman Partners in Change. (2011). Scoping report "The Learning Exchange." Aotearoa New Zealand Association of Social Workers. Auckland, NZ: Author.

Hyslop, I. (2013). The "White paper for vulnerable children" and the "Munro review of child protection in England":
ACKNOWLEDGEMENTS:

The authors wish to acknowledge the contribution of Kate Littlejohn, and Ruth Allen for data collection and analysis for this research. 
A comparative critique. Aotearoa New Zealand Social Work, 25(4), 4-14.

Hyslop, I. (2016). Social work in the teeth of a gale: A resilient counter-discourse in neoliberal times. Critical and Radical Social Work, 4(1), 21-37. doi:http://dx.doi.org/10.1332/204986016X14519919041316

Hyslop, I. (2017, April 7). Grave concerns over new ministry. Newsroom. Retrieved from https://www. newsroom.co.nz/2017/04/07/17562/smoke-mirrorsand-vulnerable-children

Lytollis, S. (1996). Making the best of the media spotlight. Social Work Now, (5), 15-20.

Merchant, R. (2012). Reframing child abuse: Changing media and public perceptions of the perpetrators of physical child abuse. Probing the boundaries. Retrieved from http://www.inter-disciplinary.net/probing-the-boundaries/ wp-content/uploads/2012/08/merchantpunpaper.pdf

Ministry of Social Development. (2015). Expert Panel final report: Investing in New Zealand's children and their families. Wellington, NZ: Author.

Ministry of Vulnerable Children Oranga Tamariki. (2017). About us. Retrieved from https://www.mvcot.govt.nz/ about-us/who-we-are/

Modernising Child, Youth and Family Expert Panel. (2015). Modernising Child, Youth and Family Expert Panel: Interim report. Wellington, NZ: Ministry of Social Development. Retrieved from https://www.msd.govt.nz/ documents/about-msd-and-our-work/work-programmes/ cyf-modernisation/interim-report-expert-panel.pdf

Nairn, R. G. (2007). Media portrayals of mental illness, or is it madness? A review. Australian Psychologist, 42(2), 138-146.

Potter, J., \& Wetherell, M. (1987). Discourse and social psychology: Beyond attitudes and behaviour. London UK: Sage.

Provan, S. E. (2012). The uncanny place of the bad mother and the innocent child at the heart of New Zealand's "cultural identity" (Unpublished doctoral dissertation), University of Canterbury, Christchurch, New Zealand. Retrieved from http://hdl.handle.net/10092/7393

Re-Imagining Social Work Collective. (2017). Who defines social work? In defence of the Global Definition. [Blogpost]. Retrieved from http://www.reimaginingsocialwork. nz/2017/05/rsw-collectives-submission-on-the-draftswrb-defintion-of-social-work/

Stanfield, D., \& Beddoe, L. (2016). Social work and social media in Aotearoa New Zealand: Educating social workers across shifting boundaries of social work identity. Social Work Education, 35(3), 28-296. doi:10.1080/02615479.2016.1154663

Staniforth, B. (2016, August 3). "Vulnerable" label harmful step for child service. New Zealand Herald. Retrieved from: http://www.nzherald.co.nz/nz/news/article.cfm?c_ id $=1$ \&objectid $=11686047$

Staniforth, B., Deane, K. L., \& Beddoe, L. (2016). Comparing public perceptions of social work and social workers' expectations of the public view. Aotearoa New Zealand Social Work, 2 (1), 1-24.

Staniforth, B., Fouché, C. B., \& Beddoe, L. (2014). Public perception of social work and social workers in Aotearoa New Zealand. Aotearoa New Zealand Social Work Review, 2 (2/3), 4-60.
Thomas, D. (2006). A general inductive approach for analyzing qualitative evaluation data. American Journal of Evaluation, 27(2), 237-246. doi:10.1177/109821400528374

Zivkovic, T., Warin, M., Davies, M., \& Moore, V. (2010). In the name of the child: The gendered politics of childhood obesity. Journal of Sociology, 46(4), 37-392. doi: $10.1177 / 1440783310384456$

Zugazaga, C. B., Surette, R. B., Mendez, M., \& Otto, C. W. (2006). Social worker perceptions of the portrayal of the profession in the news and entertainment media: An exploratory study. Journal of Social Work Education, 42(3), 62-636. 